\title{
- Cardiomyopathy etiologies and survival analysis in a cohort of patients with chronic heart failure
}

\section{Gloria Lekšić*, Jasmina Hranjec, Marijan Pašalić, Boško Skorić, Jure Samardžić, Jana Ljubas Maček, Daniel Lovrić, Hrvoje Jurin, Olvo Planinc, Dora Fabijanović, \\ Nina Jakuš, Davor Miličić, Maja Čikeš}

University of Zagreb School of Medicine, University Hospital Centre Zagreb, Zagreb,

Croatia
RECEIVED:

September 24, 2017

ACCEPTED:

September 26, 2017

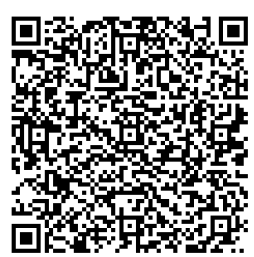

KEYWORDS: cardiomyopathy, heart failure, NT-proBNP, mortality.
CITATION: Cardiol Croat. 2017;12(9-10):355-356. I https://doi.org/10.15836/ccar2017.355

*ADDRESS FOR CORRESPONDENCE: Gloria Lekšić, Klinički bolnički centar Zagreb, Kišpatićeva 12, HR-10000 Zagreb, Croatia. / Phone: +385-1-2367-467 / E-mail: gbagadur@gmail.com

ORCID: Gloria Lekšić, http://orcid.org/0000-0003-4649-7764 • Jasmina Hranjec, http://orcid.org/0000-0001-8356-7376 Marijan Pašalić http://orcid.org/0000-0002-3197-2190 • Boško Skorić http://orcid.org/0000-0001-5979-2346 Jure Samardžić http://orcid.org/0000-0002-9346-6402 • Jana Ljubas Maček http://orcid.org/0000-0001-7171-2206 Daniel Lovrić http://orcid.org/0000-0002-5052-6559 • Hrvoje Jurin http://orcid.org/0000-0002-2599-553X Ivo Planinc, http://orcid.org/0000-0003-0561-6704 • Dora Fabijanović, https://orcid.org/0000-0003-2633-3439 Nina Jakuš, http://orcid.org/0000-0001-7304-1127 • Davor Miličić http://orcid.org/0000-0001-9101-1570 Maja Čikeš http://orcid.org/0000-0002-4772-5549

IIIIIIIIIIIIIIIIIIIIIIIIIIIIIIIIIIIIIIIIIIIIIIIIIIIIIIIIIIIIIIIIIIIIIIIIIIIIIIIIIIIIIIIIIIIIIIIIIIIIIIIIIIIIIIIIIIIII Introduction: Accounting for the largest number of hospitalizations, heart failure (HF) currently creates a large burden on the health systems in Europe. Myocardial diseases, one of the most frequent causes of HF, are predominantly represented by ischemic cardiomyopathy (ICM), while hypertrophic cardiomyopathy (HCM) is often recognized as the second most frequent form of cardiomyopathy. ${ }^{1}$ The aim of this study was to describe the etiological characteristics and survival within our HF cohort.

Patients and Methods: We performed a retrospective analysis of data from 200 patients (71\% male, mean age $47.8 \pm 11.7$ years) with mild to moderate chronic HF (NYHA II and IIIa) treated at our Department between December 2010 and December 2014. The mean follow-up period was $44.9 \pm 16.5$ months and overall survival was defined as the primary outcome of the study.

Results: The most frequent etiologies of HF included dilated cardiomyopathy (DCM) (25\%), ICM (26.5\%) and secondary cardiomyopathy (hypertensive, valvular, toxic) (19.5\%), while HCM accounted for only $8 \%$ of the cohort (Figure 1). The overall survival in our cohort was $92 \%$. No significant difference in the demographic parameters was noted among the surviving and deceased patients, except higher age and prevalence of diabetes in the deceased group. The majority of deceased patients were of DCM (8/15 deceased) and ICM (6/15) etiology. A trend towards higher overall mortality was noted in the DCM group compared to ICM, yet not reaching statistical significance $(\mathrm{p}=0.116) \quad$ (Figure 2), while multivariate analysis revealed this to be due to significantly lower EF in the DCM group. There was no significant difference in the demographic parameters, except age, among the surviving and deceased patients. By log rank test and ROC analysis, NT-proBNP provided the strongest prediction of mortality in the entire HF cohort (area under the curve 0.702, $\mathrm{p}<0.05$ ) (Figure 3)

Conclusion: Interestingly, the prevalence

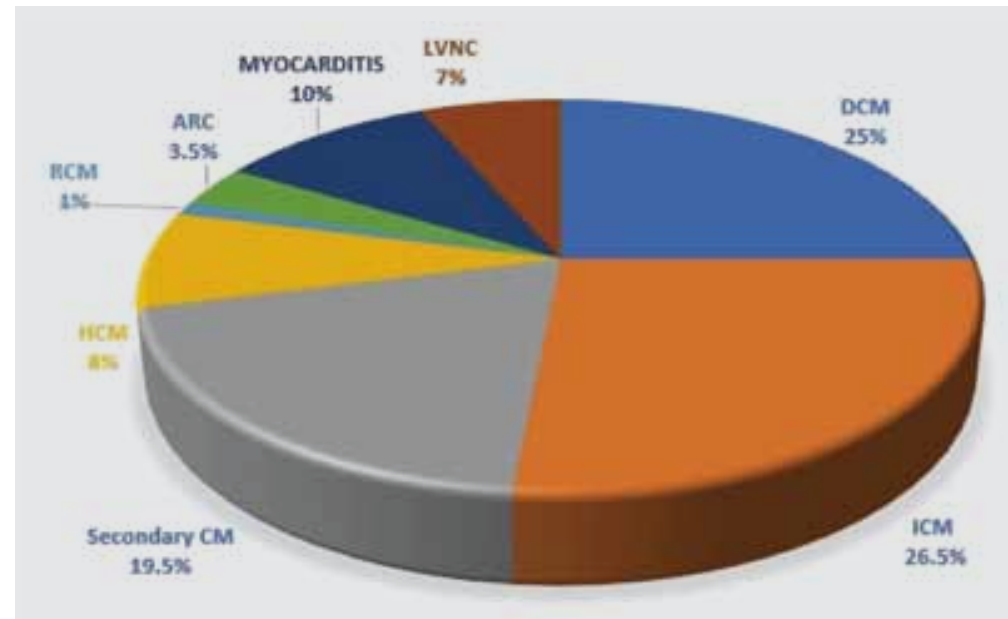

FIGURE 1. Distribution of cardiomyopathy etiologies.

DCM = dilated cardiomyopathy, ICM = ischemic cardiomyopathy, Secondary CM = secondary cardiomyopathy, $\mathrm{HCM}$ = hypertrophic cardiomyopathy, $\mathrm{RCM}=$ restrictive cardiomyopathy, ARC = arrhythmogenic right ventricular cardiomyopathy, Myocarditis = cardiomyopathy after myocarditis, LVNC = left ventricular non-compaction cardiomyopathy 

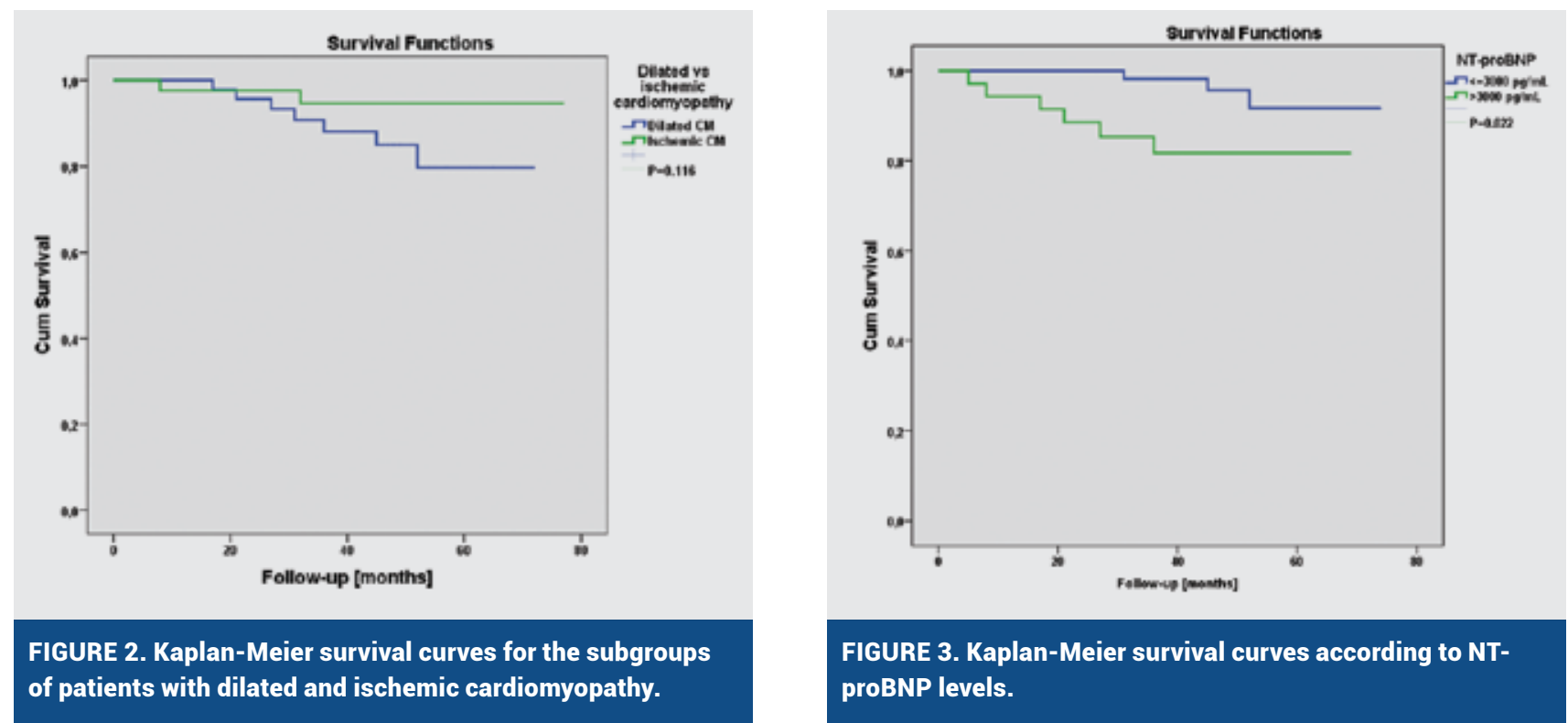

FIGURE 3. Kaplan-Meier survival curves according to NTproBNP levels.

of DCM in our cohort is much higher than that described in European registries. NT-proBNP was confirmed to be a very reliable predictor of mortality in a diverse HF cohort. Our study suggests higher mortality in DCM patients (despite a younger age) compared to ICM, but a larger patient cohort and longer follow-up time is needed to confirm this trend.

1. Maron BJ, Towbin JA, Thiene G, Antzelevitch C, Corrado D, Arnett D, et al; American Heart Association; Council on Clinical Cardiology, Heart Failure and Transplantation Committee; Quality of Care and Outcomes Research and Functional Genomics and Translational Biology Interdisciplinary Working Groups; Council on Epidemiology and Prevention. Contemporary definitions and classification of the cardiomyopathies: an American Heart Association Scientific Statement from the Council on Clinical Cardiology, Heart Failure and Transplantation Committee; Quality of Care and Outcomes Research and Functional Genomics and Translational Biology Interdisciplinary Working Groups; and Council on Epidemiology and Prevention. Circulation. 2006 Apr 11;113(14):1807-16. https://doi.org/10.1161/CIRCULATIONAHA.106.174287 